\title{
Banana Peels (Musa paradisiaca L.) Extract as Phytoestrogen on Ovariectomized Mice Mammary Gland Development by Inducing c-Myc Expression
}

\author{
Nanda Resa Pratama, Yurista Gilang, Rita Riata, Adam Hermawan, \\ Muthi' Ikawati, Edy Meiyanto*) \\ Cancer Chemoprevention Research Center (CCRC) \\ Faculty of Pharmacy Universitas Gadjah Mada Yogyakarta
}

\begin{abstract}
Hormone Replacement Therapy (HRT) is therapy for estrogen deficiency and post menopausal syndromes, but high cost and unwell-secured therapy. One of alternative therapy is the usage of phytoestrogens. The banana peel contains flavones, flavonol, flavanone and polimethoxyflavone which are potential as phytoestrogen. The purpose of this study was to examine the estrogenic effect of banana peel extract (BPE) development of mammary gland of ovariectomized rats. Estrogenic effects was examined based on in vivo and in silico experiment. For in vivo experiment, female Sprague-dawley rats aged 50 days were ovariectomized. At 70 days of age, 12 rats were treated with BPE $500 \mathrm{mg} / \mathrm{kgBB}$ and $1000 \mathrm{mg} / \mathrm{kgBB}, 5$ rats were treated with estradiol $2 \mu \mathrm{g} /$ day while others served as control were treated with CMC-Na $0.5 \%$ and sacrificed 2 weeks later. The base line ovariectomized rats and base line non-ovariectomized rats were sacrificed at 70 days of age. The in silico experiment examined by molecular docking between myricetin and estrogen receptor alpha $(E R-\alpha)$. The result of in vivo experiment showed that $1000 \mathrm{mg} / \mathrm{kgBW}$ BPE induced c-Myc expression and enhance ovariectomized rat mammary gland development significantly. Meanwhile, molecular docking showed that there are hydrogen bond interaction between bioactive compound in BPE and Estrogen Receptor (ER)- $\alpha$ but less powerfull than estrogen and ER- $\alpha$ interaction. In summary, BPE can act as an estrogen agonist, resulting in the enhancement of c-Myc expression.
\end{abstract}

Keywords: banana peels extract (BPE), phytoestrogen, mammary gland, ovariectomized rats

\section{INTRODUCTION}

Estrogen is one of the important hormones in regulating of the menstrual cycle, reproduction, modulation of bone density and cholesterol transport (Jordan, 2004). Estrogen also stimulates proliferation of breast glandular epithelial cells by binding with estrogen receptors and inducing of estrogen receptors-mediated gene transcription (Chen et al., 2000). Therefore, large amounts of estrogen deficiency causes decreasing quality of women life.

Estrogen deficiency may affect breast's health and beauty. It also triggers reproductive organs health disorder such as hot flashes (Achadiat, 2003). Estrogen deficiency usually can be treated by taking estrogen from outside of the body that is known as hormone replacement therapy (HRT). However, HRT is not only expensive but also causing breast and endometrial cancer. Therefore, an alternative therapy that is relatively safer and cheaper is the use of phytoestrogen.

Phytoestrogen is a bioactive compound that has estrogen-like structure and activity (Murkies $e t$ al., 1998). Phytoestrogen binds to and activates estrogen receptors so that it gives estrogenic effects. Sultana et al. (2008) proved that the BPE contains myricetin which is a flavonoid compound suspected as phytoestrogen.

*Corresponding author e-mail: meiyan_e@ugm.ac.id 
Myricetin is able to activate ER $\alpha$ and increase expression of c-myc so that it stimulates proliferation of breast epithelial cells MCF-7. BPE is suspected to affect breast glands development through the increasing c-myc level because it contains myricetin.

Estrogenic effects of phytoestrogen are influenced by affinity of phytoestrogen and estrogen receptor. The greater their affinity and interaction, the greater the expression of c-myc and cell proliferation. Computational method using molecular docking approach performed as a method to determine the strength of interaction between myricetin and ER $\alpha$.

This study was conducted to obtain scientific data about BPE estrogenic effects toward ovariectomized rats, that BPE could be used as a hormone replacement therapy agent.

\section{METHODS}

\section{Banana Peels Extract Preparation}

Ripe bananas were harvested from Beran, Sleman. Banana's peel was collected, dried using oven under temperature $40^{\circ} \mathrm{C}$, then it was made into powder using a blender (Maspion) and extracted with 70\% ethanol (maceration). Macerate obtained was concentrated using a rotary evaporator to obtain viscous extract.

\section{Animal Study}

Thirty six Sprague Dawley female rats 4050 days age with 86-118 grams of weight were obtained from Unit Pengembangan Hewan Percobaan (UPHP) UGM. The rats were housed in plastic cages in a temperature and humiditycontrolled room $\left(25-32{ }^{\circ} \mathrm{C}\right.$ and $98 \%$ relative humidity) and were given free access to food and distilled water. After a 3-d adaptation period, 40 mice were either sham-operated $(n=6)$ or $\operatorname{OVX}(n$ $=24)$.

\section{Treatment Groups}

The rats were randomly divided into five groups of 6 each that were ovariectomized at the age of 50 days and another group wasn't. Ovariectomy $(\mathrm{OVX})$ is an ovarian cutting process so that rats in the estrogen-deficient condition. One group of OVX mice received $0.5 \%$ CMC-Na for two weeks as a solvent control, two group of OVX mice received $500 \mathrm{mg} / \mathrm{kgBW}$ BPE and 1000 $\mathrm{mg} / \mathrm{kgBW}$ daily for 2 weeks for two weeks, some OVX mice received $17-\beta$-estradiol $2 \mu \mathrm{g}$ /day per orally. At the end of the experiment, the mice were killed with petroleum eter. In each experiment, body weights were measured and mamary were isolated for the Haematoxyllin and Eosin (H\&E) and Immunohistochemistry analysis.

\section{Haematoxyllin and Eosin (H\&E) Staining}

The first right thoracic mammary gland from each animal was carefully dissected and fixed in neutral buffered formalin for routine histopathological analysis. Briefly, mammary glands were dehydrated through a graded ethanol series, embedded in paraffin, and 5-_mthick sections cut and stained with hematoxylin and eosin. Each slide was scored on a 4-point scale ranging from 0 (normal) to 4 (severe changes) by a pathologist blinded to treatment groups. Histopathological changes were further scored according to distribution of changes ( 0.25 focal), 0.5 (locally diffuse), and 0.75 (diffuse). Therefore, the most severely affected sections with severe diffuse pathological changes would be scored a maximum of 4.75 .

\section{Immunohistochemistry}

Sections of $3 \mathrm{~mm}$ were obtained from each paraffin block of the organs. The section were washed and adhered for to poly-L-lysine-coated slides, incubated in prediluted blocking serum at $25^{0} \mathrm{C}, 10$ minutes. The slides were stained for 1 hour at room temperature with primary $\mathrm{Ab} \mathrm{c}-\mathrm{Myc}$ (Santa Cruz). After washing with phosphate buffered saline (PBS), $100 \mu \mathrm{l}$ of biotinylated universal secondary antibody (Novocastra) were applied for 10 minutes at $25^{\circ} \mathrm{C}$. The slide was incubated with streptavidin-biotin-complex for 10 minutes, $1: 2$ in PBS and 5\% Ab serum was added and washed with PBS. Slides were incubated in 3,3 diaminobenzidin (DAB) solution for 3-8 minutes and washed with aquadest. The slides were counterstained with Hematoxyllin and Eosin, 4 minutes. Protein expression was assessed under light microscope. Positive expression of c-Myc will give a dark brown color in the nucleus area.

\section{Molecular Docking}

This method was done using licensed software named 2008.10 (Chemical Computing Group Inc.). The myricetin structure was built with molecule builder and ran energy minimalizing using AM1 method. Energy minimalizing step was run to get the most stable molecule by finding the conformation with lowest energy. Era 3-D structure was taken from protein data bank (www.rcsb.org). the docking molecular was run 
between receptor active site and ligand (myricetin). The output of this method is to get ligand-receptor interaction with lowest score which has highest stability and identified ligandreceptor interaction type.

\section{Data Analysis.}

Cell morphology staining with (H\&E) and c-Myc expression were analyzed by Excell MS Office 2003 and semi-log analysis (SPSS 11.5). One way Anova was used to assess concentration $(\mathrm{p}<0.05)$ then post-hoc comparissons were made using Tuckey's significant different test. Molecular docking was done to know myricetin-ER $\alpha$ interaction. Myricetin-ER $\alpha$ interaction is getting stonger when the score is getting down.

\section{RESULTS}

\section{Effect of Banana Peels Extract in Ovariectomized Mice Mamary Gland}

Quantitative HE analysis, carried out in a wide series of rat mamary glands showed that ovariectomized made any differences on mice mamary gland lobulus (Fig.1b). Mamary gland growth was greater in mice treated BPE 1000 $\mathrm{mg} / \mathrm{kgBW}$ (Fig.1f) and treated estradiol (Fig.1d) when compared with that of ovariectomized control. BPE-treated (Fig.1e) and CMC-Na treated (Fig.1c) animals were not significantly different from each other. However, size of lobulus cell on mice treated BPE $1000 \mathrm{mg} / \mathrm{kgBW}$ and estradiol are relatively bigger than lobulus on nonovariectomized mice.

Statistically $(p>0.05)$, ovariectomized on ovariectomy mice decreased the amount of lobulus even it was not significant toward nonovariectomy mice groups (Fig.2). Estradiol significantly increased the amount of cell lobulus. On BPE $500 \mathrm{mg} / \mathrm{kgBW}$ treated groups, increased lobulus cell unsignificant towards CMC-Na treated groups. BPE $1000 \mathrm{mg} / \mathrm{kgBW}$ enhanced lobulus cell proliferation significantly towards ovariectomized control (Fig.2). No significant differences between the amount of lobulus cell among mice treated BPE $500 \mathrm{mb} / \mathrm{kgBW}$, BPE $1000 \mathrm{mg} / \mathrm{kgBW}$ and estradiol itself.

\section{Immunohistochemistry}

Expression of c-Myc on mamary gland was determined by immunohistochemstry assay. The cell which express c-Myc will be brown nearby nucleus area. The higher the colour intensity, the higher the c-Myc expression. The expression of cMyc was positively on NOVX groups (Fig.3a), estradiol groups (Fig.3d) and BPE $1000 \mathrm{mg} / \mathrm{kgBW}$ (Fig.3f) due to brown spot with high intensity. cMyc appearance on mamary gland indicated cell proliferation.

Quantification of c-Myc expression on mamary lobulus cell (Fig.4) showed that lobulus cell in OVX groups expressed c-Myc lower than NOVX groups hile estradiol group expressed the highest c-myc. Statistically, c-Myc expression on NOVX and estradiol were unsignificant. Over all, Anova and Tuckey test showed unsignificant enhancement of c-Myc expression on each groups. Probably, the mechanism of mamary gland proliferation on BPE treated rats took another pathway. 


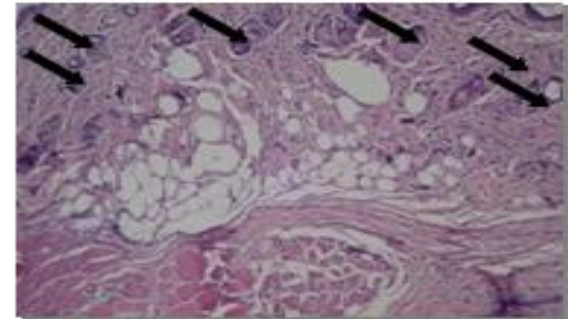

(a)

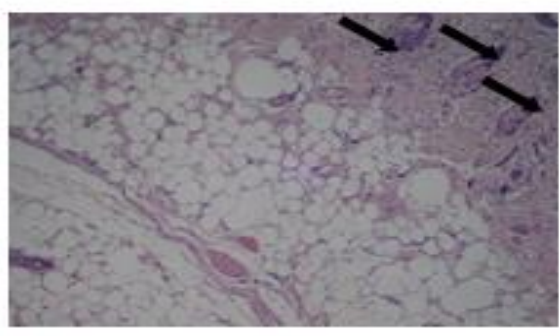

(c)

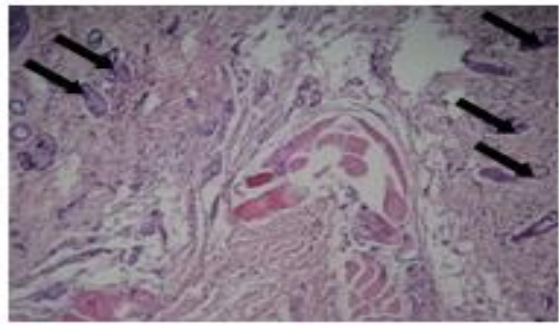

(e)

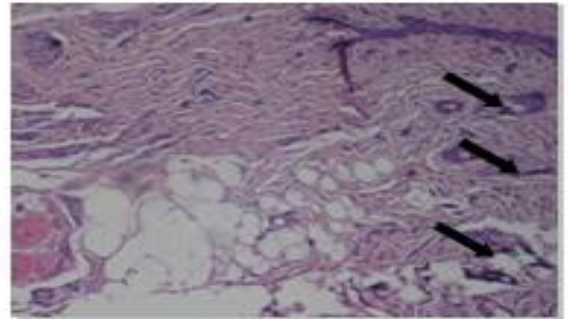

(b)

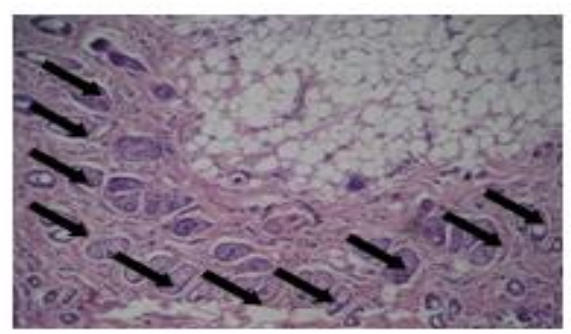

(d)

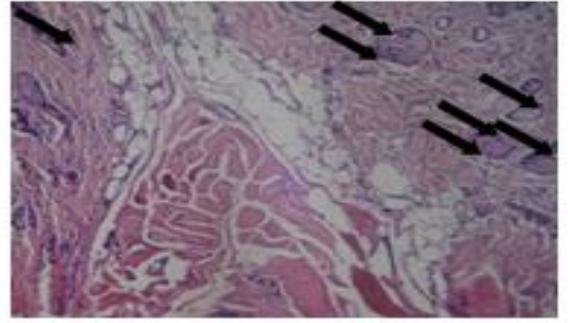

(f)

Figure I. Mice Mamary Gland Hystology (H\&E stainning). The experiments was done under light microscope with 100x magnification. Non-ovariectomized groups (a), Ovariectomized groups (b), CMC-Na groups (c), Estradiol groups (d), BPE $500 \mathrm{mg} / \mathrm{kgBB}$ groups (e) and BPE 1000 $\mathrm{mg} / \mathrm{kgBW}$ groups (f). Sign $\Rightarrow$ shows lobulus cell.

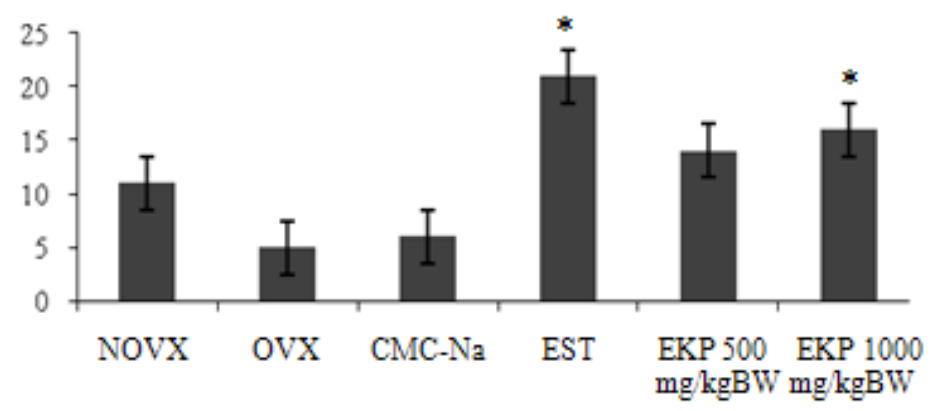

Figure 2. Quantitative Analysis of Mamary Gland Lobulus Cell (H\&E). Statistical analysis was done using ANOVA dan uji Tuckey $(p<0,05)$. Amount of lobulus was shown from average \pm standard of error (SE) of 3 experiment sign (*) showed significant differences. 


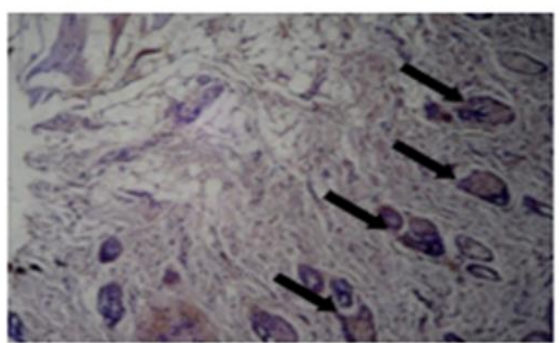

(a)

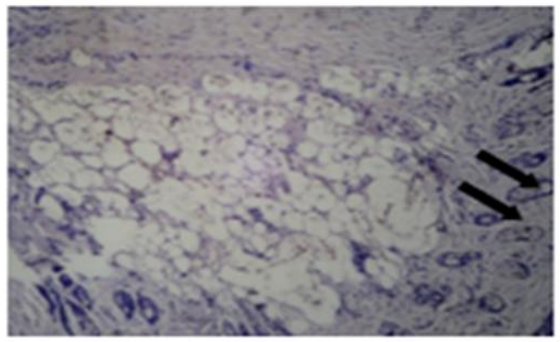

(c)

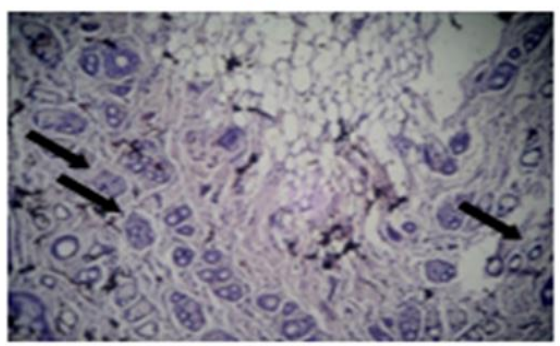

(e)

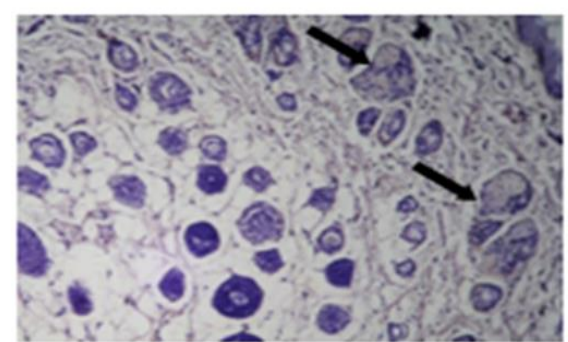

(b)

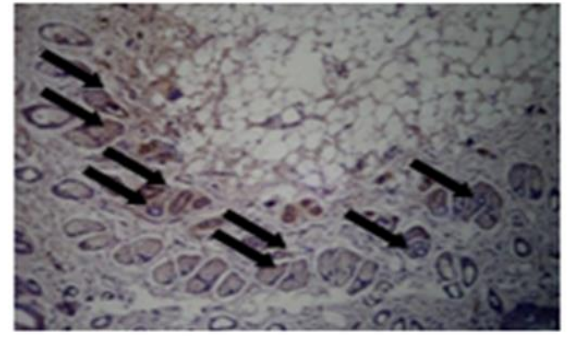

(d)

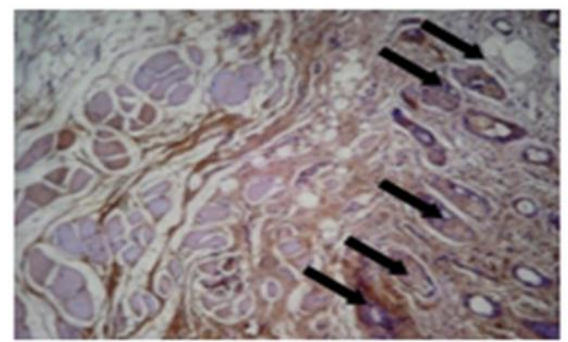

(f)

Figure 3. Determined c-Myc expression by immunohistokimia assay. The experiments was done under microscope with 100x magnification. Non-ovariectomized groups (a), Ovariectomized groups(b), CMC-Na groups (c), Estradiol groups (d), BPE $500 \mathrm{mg} / \mathrm{kgBB}$ groups (e) and BPE $1000 \mathrm{mg} / \mathrm{kgBW}$ groups (f). brown spot in cytoplasm and perinuclear show c-Myc expression. sign $\Rightarrow$ show lobulus cell which expressed c-Myc.

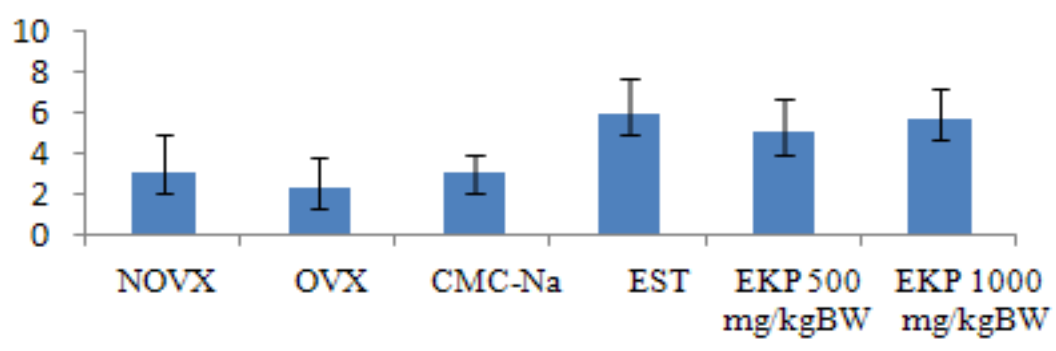

Figure 4. Quantitative Analysis of C-Myc Expression on Mamary Gland Lobulus Cell (Immunohistochemistry). Statistical analysis was done using ANOVA dan uji Tuckey $(p<0,05)$. Amount of c-Myc expression on lobulus was shown from average \pm standard of error (SE) of 3 experiment 


\section{Molecular Docking}

The interaction between ER $\alpha$ and myricetin (ligand) was predicted using molecular docking software. ER $\alpha$ structure was reached from Protein Data Bank with code 1A52. The method of docking validation use estrogen receptor and native ligand as subjects. Native ligand is estrogen (Fig.5) with Root Mean Square Deviation (RMSD) $=0,329372$. RMSD score $<2$ show that the method run with high validity. This method could<smiles>C[C@]12CCc3cc(O)ccc3[C@H]1CC[C]1[C@@H](O)CC[C@H]12</smiles>

Figure 5. Structure of estrogen

The interaction between estrogen and ER $\alpha$ (Fig.7a and 8a) is two interaction of hydrogen bonding. The hydrogen bond occured between oxygen on 17-hydroxy groups with hydrogen on hystidin 524 residu (Fig.7a) and between hydrogen on 3-hidroxy groups with oxygen carbonil on 353 glutamic acid residu (Fig.7a).

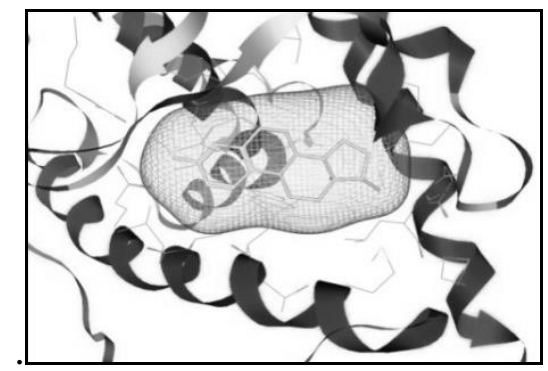

(a) predicted the position of ligand on receptor active site, ligand-receptor binding and the strength of ligand-receptor binding. The ligand on this method is myricetin (Fig.6) which is the bioactive compound on BPE. The active sited receptor placed by myricetin and estrogen (Fig.7) showed that both compound placed the same site on receptor but with different posed.<smiles>O=c1c(O)c(-c2cc(O)c(O)c(O)c2)oc2cc(O)cc(O)c12</smiles>

Figure 6. Structure of myricetin

Interaction between myricetin and $\mathrm{ER} \alpha$ (Fig.7b and 8b) is two interaction of hydrogen bonding. The hydrogen bond occured between hydrogen on 4-hidroxy groups with oksignen carbonil on histidin 353 residu (Fig.7b) and between hydrogen on 5-hydroxy groups with oxygen carbonyl on 346 leucin residu (Fig. 7b).

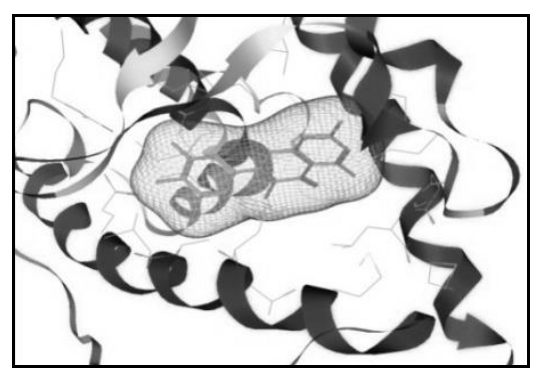

(b)

Figure 7. 3D docking result appearances. Estrogen (a) and myricetin (b) bind in the same place on estrogen receptor alfa with different pose. 


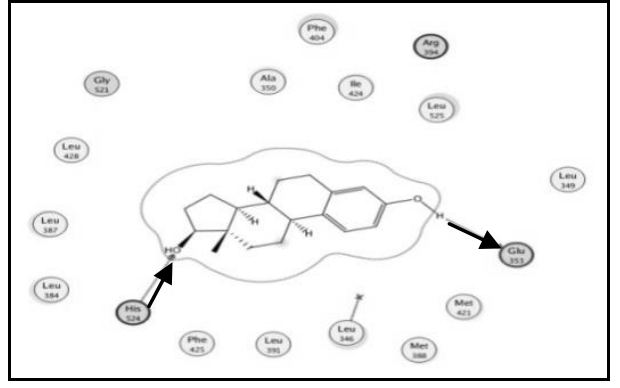

(a)

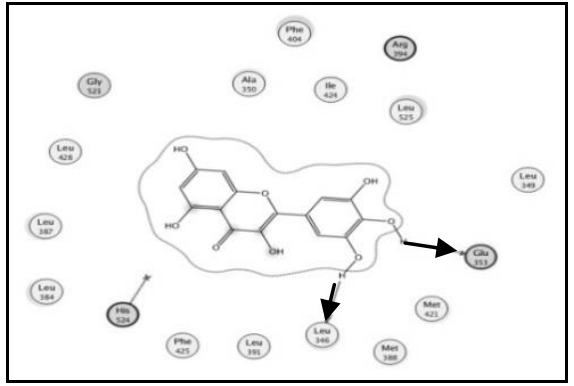

(b)

Figure 8. 2D profile of ligand-amino acid residu on receptor. Hydrogen bond interactions between hystidin 524 and glutamic acid 353 group of estrogen (a) whereas myricetin (b) make a hydrogen bond interaction between glutamic acid 353 and leusin 346. sign $\longrightarrow$ showed Hydrogen bond between ligand and amino acid residu on receptor.

The strength of ligand-receptor bonding was shown by docking score using London dG Scoring so that ligand bond with certain poses could be estimated. The lower the score, the more optimal ligand pose so that the bonding was getting stronger and stable. The molecular docking result showed that estrogen- ER $\alpha$ interaction gives lower score than myricetin- ER $\alpha$ interaction (Table 1). It showed that myricetin- ER $\alpha$ interaction is less powerfull than estrogen- ER $\alpha$ interaction.

Table I. Molecular docking score of Estrogen Receptor (Era).

\begin{tabular}{cc}
\hline Ligand & Score (kkal/mol) \\
\hline Estrogen & $-25,1793$ \\
Myricetin & $-15,5834$ \\
\hline
\end{tabular}

\section{DISCUSSION}

Estrogenic effect as in vivo could be examined from the amount of mamary lobulus cell and c-Myc expression upregulation. Estradiol enhance the amount of mamary lobullus cell significantly. BPE $500 \mathrm{mg} / \mathrm{kgBW}$ treated groups, mammary lobulus cell increased unsignificantly towards CMC-Na treated groups. BPE $1000 \mathrm{mg} / \mathrm{kgBW}$ enhanced lobulus cell proliferation significantly towards ovariectomized control. Expresssion of c-Myc was high on NOVX, estradiol, and BPE 1000 $\mathrm{mg} / \mathrm{kgBW}$ groups.

In silico experiments with molecular docking showed model interaction between estrogen receptor with the ligand. The result showed that myricetin could have such an interaction with ER $\alpha$ through hydrogen bonding and placed the same active site as estrogen. However, myricetin-ER $\alpha$ bonding was less powerfull than estrogen-ER $\alpha$. This phenomena showed that estradiol group has higher lobulus cell amount and c-Myc expression than BPE $1000 \mathrm{mg} / \mathrm{kgBB}$.

However, the interaction of agonists and antagonists could not be ascertained with this computational method and there is the possibility of other flavonoids which are more capable to produce estrogenic effect, or perhaps other flavonoids blocked myricetin affinity to ER $\alpha$. Thus, this needs to be proven by further studies with other compounds contained in BPE test and molecular docking of all flavonoid compounds in BPE.

Probably, bioactive compound on BPE (myricetin) is a phytoestrogen due to interaction with estrogen receptor so that induces mamary lobulus cell proliferation. According to Sultana $e t$ al. (2008), one of BPE bioactive compound is myricetin. Maggiolini et al. (2005) on their research said that myricetin could enhance 
mamary lobulus cell proliferation. Probably, myricetin promotes mamary epithelial growth via certain pathway and activates estrogen receptor by binding with the receptor. Those activated receptor are going to bind with Estrogen Response Element (ERE) (Van der Woude et al., 2005) and induces estrogen responsive gene expression, one of them is c-Myc expression. cMyc and cyclin D are G1 phase regulatory protein so that those could induces phase G1 cycle cell (Gardner et al., 2003).

Some protein such as c-Myc and cyclin D play a role in transition step between G1 Phase and S phase. Those induces cyclin E-Cdk2-p130 complex formation and cyclin E-Cdk2-p21 inactive complex deformation (Doisneau-Sixou et al., 2003). Cyclin E-Cdk2 complex that release from $\mathrm{p} 21$, will bind with $\mathrm{p} 130$ that phosporilated E2F-pRb inactive complex become free E2F stimulating $\mathrm{S}$ phase. But, the proposed mechanism needs to be explored further to know the exact mechanism of BPE.

Overall, this research showed that BPE has an estrogenic effect proved by enhancing mamary lobulus cell and c-Myc expression. So that, BPE is a potential herbs to be explored further as estrogen-deficiency drugs. Probably myricetin promotes mamary epithelial growth via certain pathway that needs to be explored further.

\section{CONCLUSION}

BPE dose $1000 \mathrm{mg} / \mathrm{kgBW}$ enhances mamary gland development and induces c-Myc expression significantly. The molecular docking showed the bioactive compound on BPE have a good interaction with ER $\alpha$ through hydrogen bound and placed the same active site with estrogen but estrogen- ER $\alpha$ binding is much stronger and stable.

\section{ACKNOWLEDGEMENT}

This work was supported by DUE LIKE/PPKB UGM (Peningkatan Pertumbuhan Kepemimpinan Berkualitas) 2009.

\section{REFERENCES}

Achadiat, C.M., 2003, Fitoestrogen untuk Wanita Menopause,

http://situs.kesrepro.info/aging/jul/2003/ag 0I.htm, accessed September 2010.

Chen, X., Danes, C., Lowe, M., Thaddeus, W., Herliezek and Keyomarsi, K., 2000, Activation of the Estrogen-Signaling Pathway by $\mathrm{P} 2 \mathrm{I}^{\mathrm{WAF} / \mathrm{CIPI}}$ in Estrogen Receptor-Negative Breast Cancer Cells, J. Natl. Cancer Inst., 92, 17, |403-|4|3.

Doisneau-Sixou, S.F., 2003 Estrogen and Antiestrogen Regulation of Cell Cycle Progression in Breast Cancer Cells. Endrocrine-Related Cancer, I 0, I79-186.

Gardner, L., Lee, L. and Dang, C., 2002, The cMyc Oncogenic Transcription Factor. Encyclopedia of Cancer, 2.

Jordan, C.V., 2004, Selective Estrogen Receptor Modulation: Concept and Consequences in Cancer, 5, 207-2I3.

Maggiolini, M., Recchia, B., Catalano, V., Carpino, R.V., Rossi, R. and Ando, S., 2005, The red wine phenolics piceatannol and myricetin act as agonists for estrogen receptor $\alpha$ in human breast cancer cells, Journal of Molecular Endocrinology, 35, 269 281.

Murkies, A.L., Gisela, W. and Susan, R.D., 1998, Phytoestrogen, Journal of Endrocrinology and Metabolism, 83(2), 297-303.

Sultana, B., Farooq, A., Muhammad, R.A. and Shahzad, A.S.C., 2008, Antioxidant potential of extracts from different agro wastes: Stabilization of corn oil, Grasas $Y$ Aceites, 59(3), 205-2I7.

Van der Woude, H., Ter Veld, M.G., Jacobs, N., Van der Saag, P.T., Murk, A.J. and Rietjens, I.M., 2005, The Stimulation of Cell Proliferation by Quercetin is Mediated by The Estrogen Receptor, Mol. Nutr. Food Res., 49(8), 763-77I. 